Supplement of

\title{
Influence of anthropogenic emissions and boundary conditions on multi-model simulations of major air pollutants over Europe and North America in the framework of AQMEII3
}

Ulas Im et al.

Correspondence to: Ulas Im (ulas@envs.au.dk)

The copyright of individual parts of the supplement might differ from the CC BY 4.0 License. 


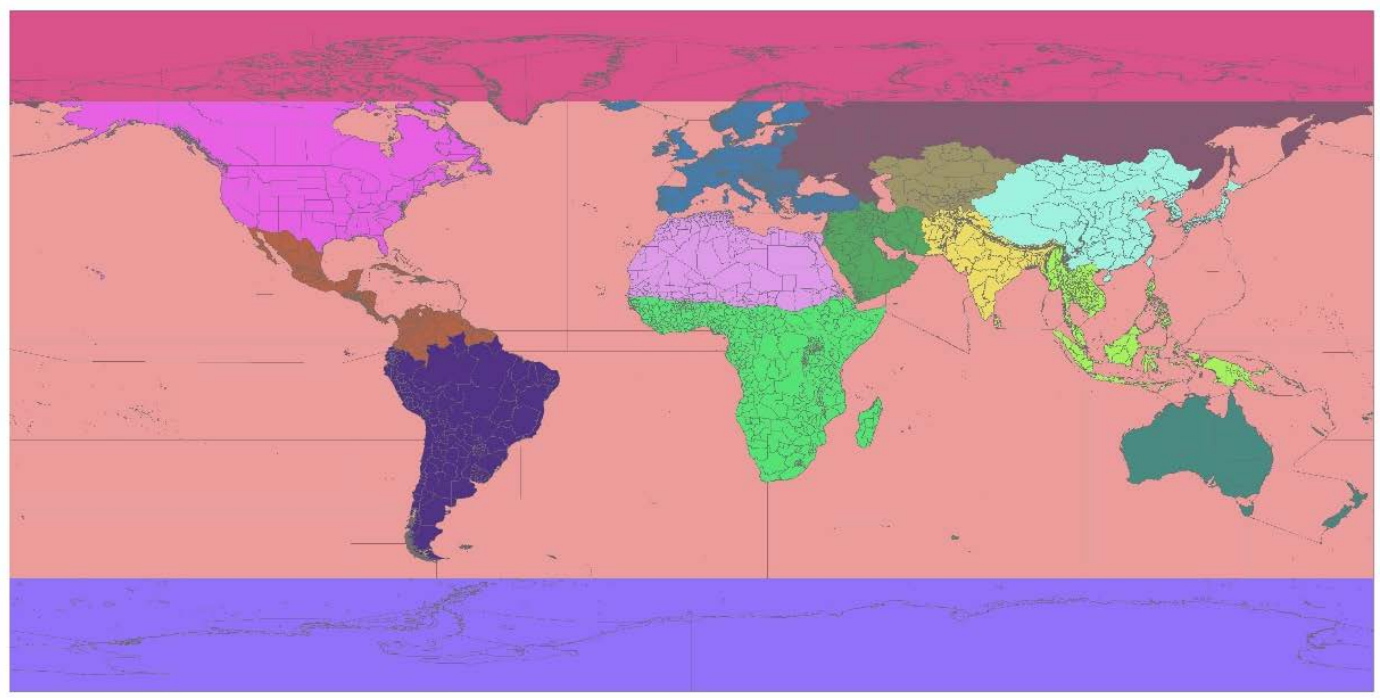

Fig. S1. The HTAP2 regions of source/receptor areas (Taken from Galmarini et al. (2017)) 

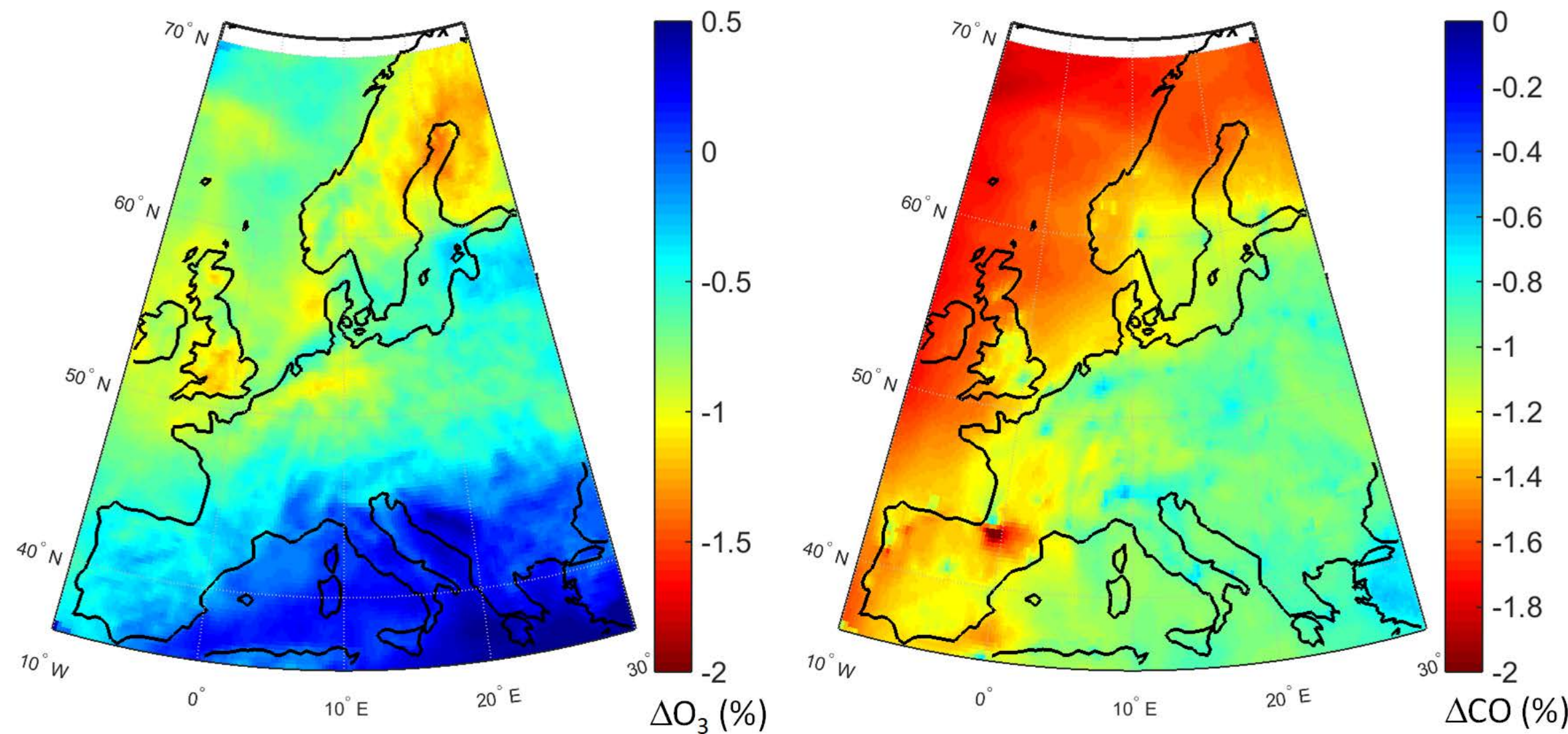

Fig. S2. Response of European springtime $\mathrm{O}_{3}$ and $\mathrm{CO}$ levels to the $20 \%$ reduction if the North American anthropogenic emissions (NAM) 

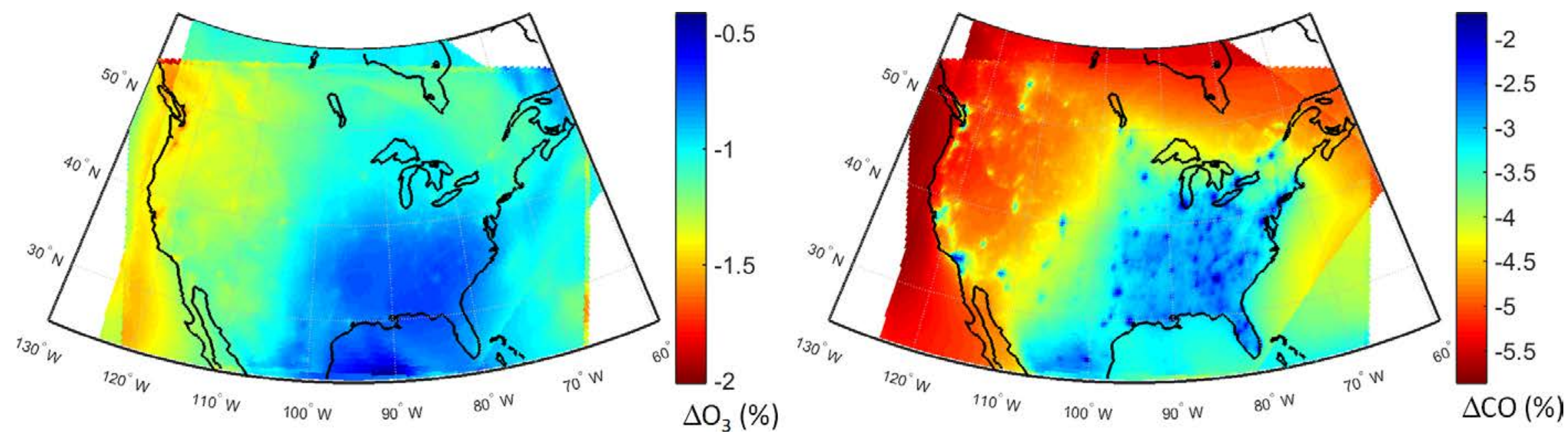

Fig. S3. Response of European springtime $\mathrm{O}_{3}$ and $\mathrm{CO}$ levels to the $20 \%$ reduction in the East Asian anthropogenic emissions (EAS). 